\title{
Što donosi moderna monetarna teorija?
}

\author{
MARKO GRDEŠIĆ \\ Fakultet političkih znanosti, Sveučilište u Zagrebu
}

\begin{abstract}
Sažetak
Ovaj rad daje kritički pregled Moderne monetarne teorije (MMT). Riječ je o pristupu ekonomskoj politici koji naglasak stavlja na autonomnu ulogu države, na njen monopolni položaj u sferi izdavanja novca te na mogućnost države da osigura punu zaposlenost kroz program zajamčenog zaposlenja. Rad iznosi glavne teorijske i policy elemente MMT-a, a zatim prikazuje glavne kritike koje se upućuju MMT-u iz liberalne, kejnzijanske i marksističke perspektive. Osim toga, ovaj rad raspravlja i mogućnost da periferne zemlje, poput Hrvatske, primijene ekonomske alate koje preporuča MMT. S obzirom na to da je MMT prešao s terena relativno marginalnih akademskih debata na teren šire političke javnosti, može se očekivati da će utjecati na ekonomsku agendu u narednim godinama.
\end{abstract}

Ključne riječi: Moderna monetarna teorija, kejnzijanizam, postkejnzijanizam, neoliberalizam

\section{Uvod}

Moderna monetarna teorija (MMT) je ekonomski pristup koji je u posljednjih nekoliko godina prešao s margina akademskih debata u fokus šire javnosti. Riječ je o sustavu ideja koje su se razvijale posljednjih dvadesetak godina unutar heterodoksnih i postkejnzijanskih ekonomskih institucija, časopisa i blogova, prije svega u SAD-u. S obzirom na kontinuiranu delegitimaciju neoliberalne ekonomske politike od velike financijske krize 2008. godine, može se očekivati da će alternative poput MMT-a zadobivati sve veću pažnju. Osim toga, nepredviđeni globalni šokovi poput epidemije COVID-19 u proljeće 2020. godine pokazuju da se neke ideje kompatibilne s MMT-om mogu primijeniti relativno lako i uspješno. Cilj je ovog rada dati pregled MMT-a, njegovih osnovnih teza i najvažnijih kritika.

Sažeto formulirano, MMT se temelji na razlikovanju državnog proračuna od proračuna pojedinačnih kućanstava i kompanija. Takvi akteri moraju uravnotežiti 
svoje proračune: ukoliko kane trošiti, moraju taj novac najprije uprihoditi ili ga dobiti zaduživanjem. Država nema to ograničenje dok god kontrolira svoju valutu, tj. ukoliko izdaje dekretni ili fiducijarni novac (engl. fiat money). To znači da ukoliko država želi trošiti na određene programe, ona to može i bez da prethodno prikupi novac porezima ili ga dobije putem zaduživanja. Državni deficiti nisu problem za MMT, a do ograničenja se dolazi tek kada se privreda približi punoj zaposlenosti. Tada bi daljnja potrošnja generirala inflaciju. Iz ovako postavljenog pristupa proizlazi i glavna policy preporuka MMT-a: da država može jamčiti zaposlenje svakom tko želi raditi za minimalnu plaću. U lošijim vremenima taj bi se amortizer više koristio, a u boljim bi vremenima privatni sektor mogao radnicima ponuditi bolje uvjete. Fiskalna politika dobila bi zadaću kontrole inflacije, a monetarna politika trebala bi osigurati što niže kamatne stope.

MMT je u sukobu s prevladavajućim pogledom na ekonomsko upravljanje, bilo da je riječ o neoliberalizmu, ordoliberalizmu ili nekom drugom obliku fiskalnog konzervativizma. Dok mainstream pristup uvijek sugerira određenu dozu štednje (engl. austerity) i "zdravih financija" (engl. sound finance), MMT daje sasvim oprečan set preporuka. Zagovornici fiskalnog konzervativizma često govore kako "nema magičnog drva na kojem raste novac" i pitaju kritičare štednje "kako ćemo si to priuštiti?" MMT sugerira da magično drvo već postoji. Takav je odgovor intrigantan jer sugerira da je distributivne sukobe moguće naprosto zaobići. Ne trebamo birati između trošenja na vojsku i trošenja na škole. U taj bismo postpolitički prostor prema MMT-u mogli ući ako se oslobodimo nekih ideja koje su ušle u "zdravi razum": da državnoj potrošnji mora prethoditi oporezivanje, da država ne može trošiti više nego što uprihoduje, da država ne može garantirati posao svim svojim građanima kojima je to potrebno. Prema zagovornicima MMT-a, zapravo se alati koje MMT opisuje već i koriste, ali selektivno i bez refleksije. Zato se ponekad tvrdi da MMT u srži i nije teorija, već opis kako stvari već funkcioniraju, prije svega u SAD-u, ali i u drugim bogatim zemljama s većom dozom monetarne suverenosti.

Prvo je ime MMT-a Randall Wray, čije su knjige i dalje najsustavniji i najpristupačniji uvodi u MMT (Wray, 1998; 2015; Mitchell, Wray i Watts, 2019). Osim Wraya, istaknuti zagovornici MMT-a su ekonomistica Stephanie Kelton, koja uređuje blog "New Economic Perspectives"'; Warren Mosler, investitor koji je napisao nekoliko kratkih ali pristupačnih knjiga o MMT-u (Mosler, 2013 [1995]; 2010); Australac Bill Mitchell, koji je jedini istaknuti zagovornik MMT-a koji ne dolazi iz SAD-a; te Pavlina Tcherneva, koja je otišla najdalje u razradi koncepta zajamče-

1 Ondje se nalazi i pristupačan uvod u MMT: http://neweconomicperspectives.org/modern-monetary-theory-primer.html (pristupljeno 23. travnja 2019). Taj je vodič u tiskanom obliku ponuđen u Wrayovoj knjizi Modern Money Theory (Wray, 2015). 
nog zaposlenja. ${ }^{2}$ Od ključnih institucija na kojima se razvija MMT treba spomenuti Levy Institute na Bard College u državi New York i Odsjek za ekonomiju na University of Missouri - Kansas City, gdje je više istaknutih MMT-ovaca radilo dugi niz godina. Među simpatizere se ubrajaju i poznati heterodoksni ekonomisti kao što su Steve Keen (2017) i James Galbraith (2019).

Vremenom se krug ekonomista koji u većoj ili manjoj mjeri odobravaju ideje MMT-a kontinuirano povećava. Može se očekivati da će buduće ekonomske krize nastaviti delegitimaciju neoliberalnih ideja te da će interes za MMT rasti. Izbijanjem pandemije COVID-19 mnoge su zemlje usvojile mjere koje podsjećaju na one koje preporuča MMT. S obzirom na to da neki čak tvrde da smo danas svi postali MMT-ovci, treba jasno razlučiti nove mjere koje provode središnje banke od onoga što predviđa MMT (vidi Nersisyan i Wray, 2020). Nije svaka heterodoksna monetarna politika ujedno i MMT. Pri tome se pokazuje da su razlozi za paniku kod provedbe heterodoksnih monetarnih rješenja uglavnom neopravdani (Blanchard i Pisani-Ferry, 2020), što osnažuje i argument za širu primjenu MMT-a.

Ovaj rad će najprije sažeto iznijeti osnove MMT-a, s naglaskom na glavne teorijske i policy točke, te zatim iznijeti glavne kritike koje su upućene MMT-u od liberalnih, kejnzijanskih i marksističkih autora. Također, osvrnut ću se na mogućnost da siromašnije i periferne zemlje - a tu se ubraja i Hrvatska - koriste alate proizašle iz MMT-a. Kao što će se vidjeti, takve zemlje imaju više ograničenja u provođenju heterodoksne ekonomske politike.

\section{Prethodnici i utjecaji}

MMT ima korijene u nekoliko intelektualnih doprinosa i struja. Najprije, tu je "čartalizam" (lat. charta, karta, papir, zapis), pristup koji se povezuje s njemačkim ekonomistom Georgom Friedrichom Knappom (1924 [1905]). Knapp je početkom 20. stoljeća iznio tezu o državnom porijeklu novca, suprotno uobičajenoj interpretaciji koja veže nastanak novca uz trampu. Prema Knappu, novac nije nastao kao spontano rješenje za probleme trampe, već je nastao zbog želje države da utječe na ekonomsku aktivnost. Država najprije nameće svim podanicima obavezu plaćanja poreza. Da bi mogli platiti porez, svi imaju potrebu doći do novca. Država ima monopol nad tiskanjem tog novca, tj. jedino ona određuje u kojoj valuti se mora platiti porez. Na taj način svi moraju participirati u ekonomskom životu koji regulira država. Prema Knappu, novac nije roba, nego je izum vlasti. Zbog utjecaja Knappovih ideja, MMT se ponekad naziva i neočartalizmom.

Neke podudarne ideje mogu se pronaći i kod Abbe Lernera, pogotovo u radovima o tzv. "funkcionalnim financijama" (Lerner, 1943). Lerner piše taj rad za

2 Vidi niz tekstova koji su dostupni na https://www.pavlina-tcherneva.net/job-guarantee (pristupljeno 30. travnja 2019). 
vrijeme Drugog svjetskog rata, kada je SAD ušao u eksperiment s visokom zaduženošću (oko 100 posto BDP-a, što je predstavljalo udvostručenje duga) te s visokim proračunskim deficitima. ${ }^{3}$ Lerner apelira da se te lekcije iskoriste kako bi se i nakon rata trajno otklonio problem nezaposlenosti. Lernerove "funkcionalne financije" temelje se na nekoliko pravila. Država mora održavati visoku razinu agregatne potražnje. Ako postoji nezaposlenost, država može smanjiti poreze i povećati vlastitu potrošnju. Ako je previše potrošnje, država treba spriječiti inflaciju tako da smanji svoju potrošnju i poveća poreze. Isto vrijedi i za kamatne stope: država treba brinuti da kamatne stope budu takve da omogućavaju primjerenu razinu investicija. Ukoliko te operacije dovode do porasta duga ili deficita, tim gore po dug i deficit. Ovi savjeti se u osnovi podudaraju s klasičnim kejnzijanskim pristupom. ${ }^{4}$ Razlika naspram MMT-a je u tome što MMT sugerira da proračunski deficiti budu trajni, a da varira tek njihova visina.

Jedan od često navođenih utjecaja je i britanski ekonomist Wynne Godley sa svojim pristupom "sektoralnih ravnoteža". Osnovna Godleyjeva teza je da nacionalnu privredu treba promatrati iz perspektive dvostrukog knjigovodstva. Ukoliko je država u minusu, to znači da se isti taj minus mora pretvoriti u plus privatnog sektora. Za zdravlje privrede mnogo je korisnije da država bude u minusu jer to znači da je privatni sektor u plusu. Primjer koji se često navodi je kratkotrajni proračunski višak koji je SAD doživio za vrijeme predsjedničkog mandata Billa Clintona. Iako se to često navodi kao primjer dobrog upravljanja državnim financijama, državni se suficit ogledao u deficitu privatnog sektora (Kelton, 2011). Drugim riječima, dok je država imala višak novca, privatnom sektoru je novca nedostajalo. Takvo stanje nije poželjno, te se ubrzo pretvorilo u manju recesiju. Empirijsko utemeljenje za negativnu korelaciju relativno je čvrsto: kada je američka država u deficitu, privatni sektor je u plusu i obrnuto (vidi npr. Godley, 2005; Fullwiller, 2009; Wiesenthal, 2012).

Osnove za svoj specifični pogled na poreznu politiku MMT je dobio iz kratkog teksta koji je neposredno nakon Drugog svjetskog rata napisao Beardsley Ruml (1946). Naslov tog rada je indikativan: "Porezi kao izvor prihoda su zastarjeli". Prema MMT-u, porezi ne služe državi kao izvor financiranja, tj. porezi ne trebaju drža-

${ }^{3}$ Oko 25 posto BDP-a, što je i dalje američki rekord. Proračunski deficit stvoren reakcijom na epidemiju COVID-19 2020. godine mogao bi tu brojku nadmašiti, pogotovo ukoliko se dogodi i znatan pad BDP-a, kao što se očekuje (vidi projekcije koje je u travnju 2020. objavio Congressional Budget Office 2020).

${ }^{4}$ Lernerova pozicija bila je svojevrsna kombinacija socijalizma i kejnzijanizma. Zajedno s poljskim ekonomistom Oskarom Langeom Lerner se obično povezuje s idejama "tržišnog socijalizma", tj. pokušajima da se osmisli koncept upravljanja socijalističkom privredom kroz cijene u sjeni (administrativne cijene) kako bi se odgovorilo na kritiku Hayeka i Misesa o informacijskim nedostacima planiranja. 
vi da bi mogla trošiti. Ruml tvrdi da razvojem centralnog bankarstva te krajem zlatnog standarda države imaju mnogo više prostora za autonomno djelovanje. Umjesto da služe kao izvor financiranja, porezi državi služe za niz drugih svrha: stabilizaciju valute (izbjegavanje inflacije), oblikovanje imovinske distribucije (progresivno oporezivanje), kažnjavanje ili nagrađivanje pojedinih sektora i oblika ponašanja. Ruml je bio idiosinkratičan pojedinac i u ostatku tog kratkog teksta napada porez na korporativne profite (Ruml, 1946: 37-39), što je nešto što MMT ne naglašava. Međutim, njegov pogled na poreze je važan element MMT-a. Porezi su ponajprije sredstvo kojim možemo oblikovati onakvo društvo kakvo želimo. Drugim riječima, ako neka država želi oporezivati kapital i najbogatije pojedince, motiv treba biti taj da se želi umanjiti značaj tih aktera u društvu. Ali državi ne treba porez dobiven od bogatih da bi financirala svoje programe.

Naravno, korijeni MMT-a su kejnzijanski. Sam Keynes se pozitivno referirao na neke čartalističke ideje. Primjerice, u Općoj teoriji (Keynes, 2015 [1936]: 274277) s odobravanjem je komentirao stavove Silvija Gesella, ministra financija u revolucionarnoj bavarskoj državi 1919. godine. Gesell je pokušao osmisliti načine kako spriječiti gomilanje gotovine u kontekstu krize. Zamislio je eksperiment s "ovjerenim novcem": da bi novčanice zadržale vrijednost koja na njima piše, morale bi se u redovitim vremenskim razdobljima ovjeriti pečatom. To bi prisililo ljude da ne drže novac, već da ga puste u cirkulaciju. Ta je teza bila važna za Keynesovu ideju o "preferiranju likvidnosti”, tj. želji ljudi da drže novac kao osiguranje od neizvjesnosti, što izvlači novac iz privrede te stvara pritiske prema kontrakciji. Keynes u superlativima piše o Gesellovom "antimarksističkom socijalizmu” te tvrdi da će povijest više naučiti od Gesella nego od Marxa (ibid.: 275-276). U pozadini ideje o ovjerenom novcu je ideja da država kontrolira novac: da novac vrijedi jer država kaže da vrijedi.

Kada je riječ o ideji zajamčenog zaposlenja, to je nešto što MMT preuzima od vodećeg postkejnzijanskog ekonomista Hymana Minskog. ${ }^{5}$ Minsky je najpoznatiji po svojoj teoriji financijskih ciklusa, ali ujedno je među prvima formulirao prijedlog da se uspostavi program koji bi trajno eliminirao nezaposlenost. Upravo zbog svoje nestabilnosti kapitalizam periodično proizvodi duboke krize koje se očituju $\mathrm{u}$ rastu nezaposlenosti. Zajamčeno zaposlenje služilo bi kao amortizer kriznih tendencija (Minsky, 2013). Pri tome valja naglasiti da MMT ostaje na razini regulacije i stabiliziranja kapitalizma, bez pokušaja da se postojeći sustav zamijeni nekim fundamentalno novim sustavom. To znači da je MMT mnogo kompatibilniji s kasnijim radovima Minskog (1986) nego s ranijima (1975), koji su sadržavali ambiciju da se izgradi socijalizam (vidi Beggs, 2018).

${ }^{5}$ Osim intelektualnih postoje i osobne veze, jer je Minsky bio doktorski mentor Randallu Wrayu. 


\section{Moderna monetarna teorija: od povijesti novca do zajamčenog zaposlenja}

MMT često započinje pogledom unatrag, tj. stiliziranom poviješću novca. Po njegovoj interpretaciji, povijest novca je čartalna (Wray, 1998: 3. poglavlje). Riječ je o pokušajima države da utječe na ponašanje svojih podanika. Pri tome država ima jednu važnu prednost pred drugim akterima u društvu: ona može prisiliti ljude na određeno ponašanje kaznama (u konačnici i zatvorom). Kao što je govorio Hyman Minsky, svatko može tiskati novac, trik je u tome da bude prihvaćen (Wray, 2015: 5-6). Država snagom svoje zakonske obveze preuzima ulogu monopolnog kreatora novca i zatim zahtijeva od svojih podanika da joj plaćaju poreze u toj valuti. To ne čini zato što joj trebaju porezni prihodi. Dapače, logički slijed je obrnut: država najprije kreira novac, a zatim ga oporezivanjem uzima natrag. Kada ga dobije kroz poreze, država taj novac uništava. Motiv države nije u tome da prikupljenim novcem financira svoje programe, već da kontrolira ponašanje pojedinaca, koji bi inače u puno većoj mjeri bili autonomni od državne vlasti. Novac je prije svega "zakonsko i definitivno sredstvo plaćanja na određenom području" (engl. legal tender), kako ga definiraju udžbenici (npr. Lovrinović i Ivanov, 2009: 22). Novac nije izrastao odozdo, spontanom evolucijom društva, već je u njegovom nastajanju ključna uloga države. ${ }^{6}$

Takva interpretacija novca dovodi do odbacivanja kvantitativne teorije novca. Ta se teorija uglavnom povezuje s Miltonom Friedmanom (1992) i monetarizmom čikaške škole, premda ima i dugu povijest prije toga. Prema kvantitativnoj teoriji novca, inflacija se kreće gore ili dolje u onoj mjeri u kojoj središnja banka povećava i smanjuje novčanu masu. Za MMT, kapitalistička privreda je "monetarna" privreda, što znači da novac nije samo "veo". Novac nastaje kada banke odobravaju kredite. To znači da potražnja za novcem kreira njegovu ponudu, dok je kod kvantitativne teorije novca obrnuto. To ujedno znači da je iluzorno očekivati da središnje banke mogu prevladati krizu promjenom količine novca. Vrlo skromni rezultati "kvantitativnog popuštanja" nakon 2008. godine to i potvrđuju. Uza svu novu likvidnost koju su stvorile glavne središnje banke svijeta, stope rasta realnog

${ }^{6}$ Prema sve raširenijem tumačenju novca, koje je kompatibilno i s MMT-om, banke stvaraju novac svaki put kada odobre kredit, a glavno je ograničenje pri tome sam imperativ profitabilnosti te prudencijalni regulatorni okvir koji propisuje država. Središnja banka ne fiksira količinu novca koji je u cirkulaciji, barem ne u normalnim vremenima. Međutim, nužnost osiguravanja niske inflacije funkcionira kao krajnji limit kreaciji novca. To se tumačenje, koje odstupa od značajnog broja udžbenika ekonomije, danas otvoreno usvaja i u vodećim središnjim bankama svijeta (npr. McLeay i dr., 2014). Slično se tvrdi i u kejnzijanskoj interpretaciji novca (vidi Skidelsky, 2018: 100) koja kritizira tumačenje po kojem banke najprije moraju uzeti depozite da bi ih plasirale kao kredite. Pristupačan historijski pregled te teme može se naći u knjizi Davida Graebera (2013). 
standarda i dalje su slabe, investicije također, a rast produktivnosti toliko je spor da mnogi pričaju o "sekularnoj stagnaciji" (Summers, 2014; Stiglitz, 2018). Pri tome sva nova likvidnost koja je nastala s "kvantitativnim popuštanjem" nije prouzročila inflaciju, što ozbiljno dovodi u pitanje uvjerljivost kvantitativne teorije novca. Osim toga, današnje se središnje banke $u$ bogatim zapadnim zemljama i ne ponašaju onako kao što je predlagao Friedman - da kontroliraju rast novčane mase - već se umjesto toga fokusiraju na kamatne stope (Wray, 1998: 2).

MMT zato zaključuje da država ima mnogo više manevarskog prostora nego što se obično smatra te da novac može biti instrument kojim se može postići mnogo toga. Država nije poput pojedinačnih kompanija ili kućanstava (Mitchell, 1998: 548; Mosler, 2010: 13-31; Wray, 2015: x). Njen proračun nema ista ograničenja. Ukoliko država ima svoju valutu, ona nikad ne može bankrotirati niti joj može ponestati novca. Kućanstva ili kompanije imaju "tvrda budžetska ograničenja", tj. sav novac koji kane potrošiti moraju najprije uprihoditi ili do njega moraju doći zaduživanjem. Država nema to ograničenje. To ujedno znači da proračunski deficiti nisu problem. Dapače, deficiti su dobra vijest jer oni zapravo predstavljaju suficit na strani privatnog sektora.

Dakle, prema MMT-u, ne treba se pitati jesu li nam proračunski deficiti preveliki, nego jesu li dovoljno veliki (Mosler, 2010: 31-41, 67-69). Već dugo nema ni zlatnog standarda ni hibridnog sustava iz Bretton Woodsa, a vlade diljem svijeta i dalje se ponašaju kao da ista ograničenja još uvijek vrijede. Međutim, ukoliko država kontrolira svoju valutu, njoj nikad ne može ponestati novca. Također nije nužno da se prihodi države najprije osiguraju oporezivanjem. Ako država želi na nešto trošiti, samo mora kroz parlament i pomoćne službe izdati potrebna odobrenja za rashode. To je ono što MMT naziva "moć lisnice" (engl. power of the purse, vidi Hoexter, 2018). U kriznim situacijama monetarna vlast može jednostavno kreirati novac, kao što su i učinile američke Federalne rezerve za vrijeme "velike recesije" 2008. i 2009. godine. Kako? Jednostavnom promjenom brojke na ekranu (Wray, 2015: 66). Kreiranje novca u današnje vrijeme zapravo ne znači tiskanje novih novčanica, već relativno jednostavnu elektronsku operaciju.

To ne znači da nema baš nikakvih ograničenja na državnu potrošnju. Ukoliko je privreda blizu pune zaposlenosti, bilo kakva dodatna državna potrošnja pregrijala bi ekonomiju. Najlakše se to može vidjeti na primjeru radne snage. Ako su svi radnici već zaposleni, državni programi mogli bi odvlačiti radnu snagu iz privatnog u javni sektor, tj. nastalo bi natjecanje za te kadrove, što bi im podiglo cijenu te generiralo inflaciju (ibid.: 9. poglavlje). To je situacija koja se obično opisuje izrazom da "previše novca lovi premalo roba". Prema tome, postoje ograničenja koja se tiču makroekonomskih fenomena kao što su inflacija i puna zaposlenost. Ali ograničenja koja bi proizlazila iz bilo kakve nužnosti da se proračun uravnoteži su samona- 
metnuta i nepotrebna. Takva formulacija problema ujedno znači da MMT premješta odgovornost za cjenovnu stabilnost s monetarne politike (koja to danas provodi na osnovi svog utjecaja na kamatne stope ili tečaj) na fiskalnu politiku. Što se tiče kamatnih stopa, obično se savjetuje da ih monetarna vlast drži što bliže nuli.

S obzirom na navedeno, MMT tvrdi da nema razloga zbog kojih država ne bi mogla uvesti program zajamčenog zaposlenja za svakog tko treba posao, a ne može ga pronaći u privatnom sektoru (Mitchell, 1998; Mosler, 2010: 57-65; Wray, 2015: 8. poglavlje). Rad na infrastrukturi i briga za starije, djecu i okoliš su očite djelatnosti gdje bi se takav program mogao koristiti. On bi de facto definirao novu minimalnu plaću, tj. predstavljao bi najniži standard ispod kojeg privatni sektor ne bi mogao ići. Pri tome je MMT-u važno da država tim programom ne konkurira privatnom sektoru. Ako radnici žele napustiti taj program i prijeći u privatni sektor za veću plaću, država ne bi trebala ući u natjecanje za kadrove (jer bi to vodilo u inflaciju). Kontinuirana zaposlenost je veliki plus za same radnike jer čak i kratkotrajne epizode nezaposlenosti dovode do rapidnog zastarijevanja vještina, ali i niza drugih negativnih posljedica po zdravlje radnika i njegovu obiteljsku okolinu.

Uobičajena reakcija na takav prijedlog jest da bi puna zaposlenost generirala inflaciju. MMT, međutim, nudi obrnutu interpretaciju. Fiksiranje cijene rada zapravo bi stabiliziralo cijene (Wray, 1998: 123). Ukoliko država fiksira cijenu nekog resursa koji se često koristi u cijeloj privredi - primjerice, nafte - onda sprečava da se porast cijene tog resursa prelije na ostale cijene. Prije su to države činile sa zlatom kada bi fiksirale svoju valutu za njega (ibid.: 3, 136). To je stvaralo pritiske prema manjoj inflaciji, čak i deflaciji. Rad je pak mnogo važniji resurs za privredu od zlata, pa bi s uvođenjem najniže plaće kroz program zajamčenog zaposlenja cijene bile utoliko stabilnije. Je li to zaista tako jest empirijsko pitanje, ali neki ograničeni eksperimenti, poput onoga u Argentini, pokazuju da štetnih makroekonomskih posljedica nema (Tcherneva, 2013). Osim toga, taj je program zajamčenog zapošljavanja zamišljen tako da uzima radnike s "dna", a ne s "vrha". To je, naime, bila pogreška prethodnih kejnzijanskih pokušaja da se postigne puna zaposlenost: država bi ušla u natjecanje s privatnim sektorom za oskudne visokokvalificirane radnike.

U današnjem kontekstu onaj dio radnika koji je nezaposlen "služi" ostatku društva u borbi protiv inflacije (Wray, 1998: 122). S MMT-om, to bi postalo nepotrebno. Umjesto da se koristi amortizer nezaposlenih, koristio bi se amortizer zaposlenih. Danas troškove nezaposlenosti društvo ionako snosi: kroz niz štetnih posljedica, kako ekonomskih tako i osobnih i obiteljskih.

\section{Kritike: zdesna i slijeva}

MMT je izložen i raznim kritikama, kako od liberalnih ekonomista iz akademskog i političkog mainstreama tako i od onih koji problemu pristupaju iz kejnzijanske i 
marksističke perspektive. Najprije ću sažeti neke od primjedbi koje dolaze od mainstreama, a zatim prijeći na kejnzijansku i marksističku kritiku. Međutim, evidentno je da je MMT posljednjih godina zadobio visoku dozu legitimnosti kao jedan mogući pogled na ekonomsku politiku.

Kada je riječ o liberalnom mainstreamu, postoji nekoliko čestih kritika na račun MMT-a. Primjerice, Kenneth Rogoff (2019), Larry Summers (2019) i Gregory Mankiw (2019) smatraju da će MMT prouzročiti inflaciju. Rogoff kritizira i ideju da fiskalni deficiti nisu važni, a smatra i da s rastom duga treba biti oprezan. To je kompatibilno s njegovim ranijim radovima o ekonomskom rastu u kontekstu visoke zaduženosti te tezom da postoji granica zaduženosti nakon koje ekonomski rast značajno usporava (Reinhart i Rogoff, 2010; za kritiku vidi Herndon, Ash i Pollin, 2014; Blanchard, 2019). Za Summersa, MMT ponavlja grešku koju je napravila ekonomija ponude, samo s lijevim predznakom. Kao što je nekada Lafferova krivulja predviđala da će smanjenja poreza donijeti veće porezne prihode jer će se ohrabriti ekonomska aktivnost (pa su konzervativni ekonomisti tvrdili da će se isplatiti sva smanjenja poreznih stopa), tako sada MMT ponovo obećava "besplatni ručak". Na temelju kvantitativne teorije novca i Mankiw (2019) smatra da će MMT generirati inflaciju.

Slično misli i Paul Krugman (2019a; 2019b), kojeg se može smatrati klasičnim kejnzijancem. Osim problema inflacije, Krugman ističe da se MMT nepotrebno odriče monetarne politike kao instrumenta. S obzirom na to da efikasnih ekonomskih alata nema mnogo, takva je odluka nepoželjna. Isti je prigovor uputio i Palley. Kod njega se može naći najsustavnija kejnzijanska kritika MMT-a (Palley, 2015; 2019). Najprije, MMT krivo predstavlja nastanak novca. Ta kritika ne bi bila toliko važna da zagovornici MMT-a ne koriste stiliziranu interpretaciju povijesti kako bi svoje uvide predstavili kao transhistorijske. Glavna je poanta MMT-a ta da je povijest novca čartalna, što ne odgovara uvijek empiriji (Palley, 2019: 2526). Rani novac vezan je uz razne forme metalnog standarda, dok novac u obliku papirnatih novčanica dolazi relativno kasno. Ta je distinkcija važna jer postojanje fiksne količine zlata i srebra ograničava državu u pokušaju da kreira novac ni iz čega. Države u toj situaciji moraju ili oporezivati ili se zaduživati kako bi došli do novca (ili u kolonijama tražiti zlato kao što su pokušavale sve velike sile). SAD je tek 1970-ih, kada je Richard Nixon raskinuo vezu dolara i zlata, uistinu prešao na čartalni novac.

Kada je riječ o srži MMT-a, Palley tvrdi da taj pristup nudi mješavinu starih i novih teza, $\mathrm{s}$ time da su stare teze provjerene i općeprihvaćene, a da su nove pogrešne. Naime, dobro je poznato da države imaju više prostora da kreiraju novac kroz potrošnju: to je ono što kejnzijanci također naglašavaju kada zagovaraju državno upravljanje agregatnom potražnjom. Međutim, stari su kejnzijanci imali sofistici- 
raniji pogled na proces državnog upravljanja potražnjom pri čemu se država može suočiti s više ograničenja nego što MMT priznaje (ibid.: 8). To uključuje fenomene poput bilance plaćanja, tečajne politike, problema stabilnosti na financijskim tržištima te Phillipsove krivulje koja predviđa nužan odabir između nezaposlenosti i inflacije (ibid.: 12).

Također se pojavljuje i pitanje implementacije. Naime, država nije toliko sposobna koliko bi trebala biti da bi uspješno provodila politike koje MMT predlaže. Fiskalna politika ne može djelovati dovoljno brzo u podizanju poreza kada se privreda približi punoj zaposlenosti. Kašnjenja koja nastaju zbog političkog procesa mogla bi dovesti do krivovremenih reakcija, a možda i do reakcija koje bi djelovale prociklički umjesto anticiklički (ibid.: 9). Političari, koji upravljaju fiskalnom politikom, ne vole dizati poreze i rezati potrošnju jer je to nepopularno. Osim toga, MMT pretpostavlja da su ministarstvo financija i središnja banka povezani do te mjere da se mogu tretirati kao jedna institucija (vidi također Lavoie, 2013). To najčešće nije tako u praksi, a trend rasta nezavisnosti središnjih banaka od osamdesetih godina do danas učinio ih je zaštićenim od svakodnevne politike.

Kada bi MMT uspio presložiti institucionalnu strukturu tako da primjena njegovih rješenja bude uspješnija, vrlo je vjerojatno da bi financijska tržišta na to gledala vrlo negativno. Očekivanja privatnog sektora sasvim su izvan razmatranja MMT-a unatoč kejnzijanskim korijenima tog pristupa. Očekivanja prema budućnosti utječu na ponašanje u sadašnjosti, tako da budućnost nikada nije samo budućnost, već je prisutna i u sadašnjosti (Palley, 2019: 12-13). Prema tome, moguće je da će privatni sektor (kapital) u svoja očekivanja ugraditi inflatorne pritiske zbog konstantnog kreiranja novca putem fiskalne politike. S obzirom na to da privatni sektor kontrolira veći udio investicija od javnog, to predstavlja problem za MMT. Drugim riječima, MMT ignorira političko-ekonomsku konstelaciju snaga. Sličnu kritiku MMT-u upućuju i marksistički autori.

Opsežna marksistička kritika MMT-a može se naći kod dva autora, Michaela Robertsa (2019a; 2019b; 2019c; 2019d; 2019e) i Douga Henwooda (2019). Najprije, marksizam može kritizirati MMT na temelju svoje teorije vrijednosti. Za razliku od MMT-a, marksizam stavlja naglasak na kreiranje nove vrijednosti kroz proizvodni radni proces. U tekstovima MMT-a realni se svijet poduzetnika (kapitalista) i radnika gotovo uopće ne pojavljuje. MMT nema teoriju vrijednosti, premda su neki zagovornici MMT-a otvoreni za tu raspravu (Wray, 1999). Kod Marxa kapitalisti moraju stvoriti novu vrijednost da bi došli do profita, a to mogu samo kupovanjem radne snage. Samo kroz ljudski rad nastaje višak vrijednosti koji kapitalisti mogu eksploatirati. Prema tome, kapitalizmu je pogonsko gorivo profitni motiv, a ne novac. Ukoliko profitna stopa padne, kao što se predviđa u marksističkoj tezi o tendenciji profitne stope da padne, onda privreda ulazi u probleme. 
Tu nije riječ tek o Keynesovim “životinjskim nagonima” (engl. animal spirits) kojima se vode kolebljivi investitori na financijskim burzama, već o sistemskom problemu. Iz tih problema neće biti moguće izaći bilo kakvim monetarnim makinacijama i sličnim "trikovima cirkulacije", kao što ih u Grundrissima naziva Marx, već tek oporavkom profitne stope. Kao što Michael Roberts i drugi marksisti dokumentiraju, profitna stopa je za bogate zapadne zemlje u padu već više desetljeća (Roberts, 2017; vidi također Shaikh, 2016: 65-68). Marx bi vjerojatno MMT-u prigovorio da zatvara oči pred klasnim sukobom i stavlja sve nade na novac upravo zato da bi se trikovima cirkulacije izbjegao nužno nasilni karakter revolucionarnih promjena (Marx i Engels, 1979 [1939]: 34). Međutim, promjene koje MMT predlaže mogle bi zahtijevati veliko rekalibriranje odnosa snaga u društvu. Ne treba podcijeniti mogućnost da MMT bude suočen s otporom kapitala.

Za Marxa novac tek "predstavlja" vrijednost koja nastaje kroz radni proces. To znači da je novac vezan za ono što se događa u proizvodnji. Država može izdavati novac, ali ne kontrolira njegovu cijenu. Novac može izbjeći inflaciju (pad vlastite vrijednosti) samo ako je potkrijepljen efikasnim proizvodnim sektorom. Proizvodnja privatnog sektora jest ono što u kapitalizmu daje vjerodostojnost državnom novcu (i državnim obveznicama). Kada to pouzdanje nestane, nestaje i vrijednost novca, kao što se događa u situacijama hiperinflacije od vajmarske Njemačke do suvremenog Zimbabvea. Država nije svemoguća u kapitalizmu, jer u kapitalizmu ključnu ulogu igra kapital. Tek kada bi država kontrolirala veći udio u BDP-u od privatnog sektora te kada bi javne investicije bile veće od privatnih, konstelacija snaga dovoljno bi se promijenila. Tada bi se značaj profitne stope smanjio te bi utjecaj privatnog sektora bio nadvladan. Zato se marksističke preporuke, kako ih iznosi Roberts (2019a), i kreću prema tome da treba prenijeti u javno vlasništvo ključne dijelove privatnog sektora, tzv. "visine s kojih se zapovijeda" (engl. commanding heights). To prije svega uključuje financijski sektor. ${ }^{7}$ Novac kreiran preko tipkovnice čini se kao zavodljiv izlaz, kao sredstvo kojim se može dobiti niz progresivnih (a možda i socijalističkih) rješenja bez ikakve potrebe da se ulazi u sukobe s kapitalom (Henwood, 2019). Za marksiste je takav pogled suviše naivan.

\section{Mogu li se i zemlje izvan jezgre koristiti MMT-om?}

Jedno je relevantno pitanje ono o široj primjenjivosti MMT-a. Može li ta teorija putovati van SAD-a? MMT obično tvrdi da njegove teze vrijede za svaku zemlju koja izdaje svoju valutu, pod uvjetom da ne veže svoju valutu za neku stranu. To bi

7 Takva bi transformacija morala uključiti i velike kompanije poput Amazona i Walmarta koje, osim što zauzimaju kvazi-monopolnu poziciju, ujedno pokazuju da već danas živimo u planskoj privredi, samo što se planiranje odvija unutar granica njihove gigantske korporativne strukture (Phillips i Rozworski, 2019). 
zasigurno obuhvatilo bogate zapadne zemlje kao što su SAD, Velika Britanija, Japan i Australija. Međutim, mnogi su kritičari upravo tu točku istaknuli kao ključnu slabost MMT-a. Za hrvatske čitatelje to je pitanje posebno važno.

MMT je osmišljen u američkom kontekstu i najlakše je zamisliti da u njemu i bude primijenjen. SAD, međutim, zauzima posebno mjesto u svjetskom ekonomskom sistemu zbog toga što tiska dolar, koji obnaša funkciju rezervne svjetske valute. To stvara ono što se često naziva "pretjeranim privilegijem" (engl. exorbitant privilege), kako je taj fenomen nazvao Valéry Giscard d'Estaing, francuski političar i bivši predsjednik (Eichengreen, 2013: 4-5; Palley, 2019: 20). Naime, velik dio međunarodnih transakcija denominiran je $u$ dolarima, a tu se pogotovo ističe trgovina naftom. Da bi kupili naftu, akteri iz drugih zemalja moraju te dolare najprije zaraditi, tj. proizvesti i prodati određene proizvode i usluge za dolare. To vrijedi čak i za niz bogatih demokracija poput Velike Britanije, Japana ili Australije. To su redom zemlje za koje MMT tvrdi da njegove teze vrijede. Siromašnije zemlje suočene su s dodatnim nizom problema. Te zemlje moraju i kapitalno intenzivnu opremu - kojom pokušavaju modernizirati svoju proizvodnju - kupovati u stranoj valuti. Turska ili Hrvatska su, primjerice, suočene s situacijom da nema mnogo moderne tehnologije koja se može kupiti u turskim lirama ili hrvatskim kunama. Dakle, takve zemlje moraju zaraditi stranu valutu i za to.

Tu ne staju problemi siromašnijih zemalja koje se nalaze izvan svjetske jezgre. Takve zemlje često su suočene s naglim ulaskom i izlaskom stranog kapitala. Čak i kada nije tako, financijska tržišta imaju znatan utjecaj na te zemlje jer gubitak povjerenja u valutu i državne obveznice može imati poguban učinak. To nisu problemi s kojima se suočava SAD. Dapače, u krizi 2008. i 2009. godine mnogo se novca slilo u američke obveznice jer su financijska tržišta procijenila da su u tako neizvjesnom trenutku američki vrijednosni papiri najsigurnija investicija. Osnovni prijedlozi koje MMT daje zemljama u razvoju jest da se ne zadužuju u stranoj valuti te da uvedu plivajući tečaj (Wray, 2015: 6. poglavlje). Međutim, mnoge zemlje često nemaju alternativu zaduživanju u stranoj valuti.

Osim toga, upitno je pruža li plivajući tečaj dovoljno zaštite od naglog kretanja "vrućeg kapitala". Kapitalne kontrole mogle bi biti dio rješenja, ali one nisu sustavni dio MMT-a. Empirija sugerira da mnoge zemlje u razvoju moraju stati mnogo prije pune zaposlenosti upravo zbog izloženosti kapitalnim kretanjima (Epstein, 2019: 12). Takva situacija može imati niz negativnih posljedica: kada se kapital povuče, tečaj deprecira, vrijednost duga naraste, kamate narastu, i to upravo u trenutku kada bi trebale biti niske da se zemlja izvuče iz krize. Strah od plivajućeg tečaja jest razuman za male i otvorene zemlje. Taj problem "stani-kreni" tim je teži što je zemlja siromašnija i oskudnija kapitalom. 
Neki su istraživači povezani s MMT-om pokušali razmotriti i zemlje u razvoju kao mjesto gdje bi se moglo započeti s eksperimentima. Primjerice, Kaboub (2012) razmatra mogućnost da Tunis uvede program zajamčenog zaposlenja. Po njegovim izračunima, takav bi program koštao relativno malo: oko tri posto BDP-a, a imao bi niz pozitivnih ekonomskih posljedica. Međutim, takvih prijedloga nema mnogo. Moguće je da će se nakon 2020. godine i u takvim zemljama osloboditi manevarski prostor za eksperimentiranje, ali veća je vjerojatnost da će politike na tragu MMT-a uvoditi zemlje koje imaju veće razine monetarne suverenosti poput Velike Britanije, Japana ili Australije.

Povrh svega, MMT bi se mogao tumačiti kao ekonomska politika koja na prvo mjesto stavlja Ameriku (engl. America-first economics) jer ne obraća mnogo pažnje na posljedice koje bi kreiranje novca kroz fiskalnu politiku te bujanje američkog proračunskog deficita imalo na ostatak svijeta (Epstein, 2019: 6). Doduše, SAD još od Nixonovog unilateralnog napuštanja bretonvudskog sustava i Volkerovog šoka osamdesetih godina vodi upravo taj tip ekonomske politike. Izostanak američke volje da snosi troškove svog hegemonijskog položaja u svijetu zapravo je simptom slabljenja te hegemonije. Međutim, ukoliko MMT ima ambiciju formulirati progresivnu alternativu, onda je važno da ona bude formulirana s internacionalističkim ciljevima.

Spomenuti problemi relevantni su i za Hrvatsku. U ovom trenutku Hrvatska je relativno nepovoljno pozicionirana da se koristi politikama utemeljenim na MMT-u. $\mathrm{Da}$ bi se prostor za takvo što proširio, trebalo bi konvertirati u domaću valutu sav dug koji postoji u stranoj valuti i kod građana i kod države. To je velik izazov za koji, trenutno, ne postoji politička volja ni izabrane ni monetarne vlasti. S preuzimanjem eura bi se pak u potpunosti zatvorilo vrata heterodoksnoj ekonomskoj politici utemeljenoj u MMT-u. Tada bi jedina mogućnost bila ta da se sama Europska središnja banka okrene eksperimentima. Nije ni tako nešto nemoguće, ali je manje vjerojatno s obzirom na političke konflikte $u$ heterogenoj i nestabilnoj eurozoni.

Ipak, treba napomenuti da interes za MMT raste čak i u Hrvatskoj. Primjerice, Sajter (2018) je napisao kratak tekst koji popularizira ideje MMT-a. U kontekstu krize uzrokovane pandemijom COVID-19 Čavrak se poziva na MMT kako bi sugerirao da HNB treba izravno financirati državni proračun, tj. bez prethodnog oporezivanja ili zaduživanja (Čavrak, 2019: 16). I drugi ekonomisti koji se zalažu za aktivniju monetarnu politiku i za korištenje monetarnog suvereniteta (primjerice Radošević i Zdunić, 2018) mogli bi u idejama MMT-a pronaći saveznika. Ukoliko broj takvih pogleda bude rastao, rast će i interes za MMT. Prema tome, ne treba isključiti mogućnost da se čak i Hrvatska koristi nekima od mogućnosti koje predviđa MMT, barem dok kontrolira vlastitu valutu. 


\section{Zaključne napomene}

Moderna monetarna teorija postala je legitimni sugovornik $\mathrm{u}$ javnim raspravama o ekonomskoj politici. S obzirom na to važno je razumjeti što takva teorija donosi i kakve politike predlaže. Ovaj rad pokušao je kritički prikazati teorijsko utemeljenje i policy agendu MMT-a. Prije svega, MMT se nametnuo u SAD-u, ali proširenu praktičnu primjenu mogao bi doživjeti i u onim bogatim zapadnim zemljama $u$ kojima postoji monetarna suverenost. Za malu, otvorenu i srednje razvijenu zemlju kao što je Hrvatska ove su rasprave ipak relativno udaljene. To je tako jer središnja banka već godinama provodi samo uhodana ortodoksna rješenja na području monetarne politike, a fiskalna se vlast nalazi u vrlo skučenom prostoru odlučivanja gdje pravila EU-a djeluju ograničavajuće. Za zemlje unutar eurozone kao i za zemlje koje vežu svoju valutu za euro u većoj mjeri vrijede tvrda budžetska ograničenja. Osim toga, ovisnost o stranom kapitalu čini konzervativnu fiskalnu i monetarnu politiku izglednijom jer je to ono što financijska tržišta očekuju.

Za bogatije zemlje koje imaju kontrolu nad svojom valutom prostor za eksperimentiranje je veći. To pogotovo vrijedi za SAD jer on tiska svjetsku rezervnu valutu, a potražnja za dolarom i za američkim državnim obveznicama je postojana. Nema sumnje da je MMT - uza sve svoje nedostatke - uspješno otvorio vrata za izlazak iz sputavajućeg okvira fiskalnog konzervativizma i neoliberalne politike štednje. Takva politika ne pokazuje se previše uspješnom, pogotovo kad se promotri vrlo spor ekonomski rast u bogatim demokracijama, spor rast produktivnosti, slabost privatnih investicija te rastuća razina nejednakosti. Glavne pouke MMT-a su važne: da država nije poput kućanstva, da država ima više diskrecijskog prostora nego što se misli, da je bolje brinuti o zaposlenosti nego o dugu itd. Istovremeno, ovaj je rad iznio i niz kritika na račun MMT-a koje se sada mogu kratko sumirati.

Najprije, MMT je pretjerano fasciniran kreiranjem novca preko tipkovnice. Ta se mogućnost pretvara u magični štapić. I dalje ostaje otvoreno pitanje hoće li privatni sektor takvoj politici pružiti otpor ili će joj se prilagoditi. Puna zaposlenost, koju MMT želi postići svojim programom zajamčenog zaposlenja, donosi i određene političke posljedice. Ako država može postići punu zaposlenost bez privatnog kapitala, onda utjecaj kapitala slabi. Zato treba očekivati da će biti mnogo onih koji će biti protiv tog prijedloga. U viziji MMT-a država je gotovo svemoguća, a kapital sasvim nevidljiv. S tim je povezan i problem da MMT olako pretpostavlja kako su postojeći birokratski i regulatorni mehanizmi dovoljno sofisticirani da upravljaju privredom čak i kada je ona na granici pune zaposlenosti. Za očekivati je da i najbogatije zemlje svijeta ipak nemaju birokratski i politički aparat koji je sposoban djelovati tako efikasno i pravovremeno.

Glavni policy prijedlog koji iznosi MMT jest zajamčeno zaposlenje. U današnjim će raspravama zagovornici MMT-a morati objasniti javnosti zašto je taj pri- 
jedlog bolji od svog konkurenta, zajamčenog temeljnog dohotka. Ta je ideja već zadobila priličnu popularnost i kod liberalnog dijela javnosti kojem se dopada postmoderni naglasak na individualnosti i kod lijevog dijela javnosti kojem se dopada osnaživanje rada vis-à-vis kapitala. I dok se ideja temeljnog dohotka testira na nizu mikrostudija u više zemalja, eksperimenti sa zajamčenim zaposlenjem praktički i ne postoje. Doduše, makroekonomske posljedice i jednog i drugog prijedloga neće biti vidljive dok se neka zemlja ne odvaži da bilo jedan bilo drugi sustav trajno uvede na nacionalnoj razini. Problemi s inflacijom i poreznim opterećenjem vise nad glavom i jednog i drugog prijedloga. Zasad treba primijetiti da još nema odgovora na pitanje bi li ljudi preferirali autonomiju koju im nudi ideja temeljnog dohotka ili bi radije obavljali društveno korisne poslove za nisku plaću kao što im nudi ideja zajamčenog zaposlenja.

MMT je važan teorijski iskorak za heterodoksnu ekonomsku teoriju i politiku. U današnje je vrijeme neoliberalizam izgubio velik dio legitimacije koju je imao prije "velike recesije" i prije epidemije COVID-19. U tom je kontekstu idejna konkurencija i više nego dobrodošla. Zalaganje za eksperimente od velike je važnosti s obzirom na dugogodišnje ponavljanje neoliberalne mantre da "nema alternative". Hrvatska nije posebno povoljno pozicionirana da sudjeluje u provođenju inovativnih ekonomskih politika o kojima se govorilo u ovom tekstu. Međutim, valja očekivati da će se rasprave koje se vode u zapadnim zemljama prelijevati i na javni prostor naše zemlje. Cilj ovog rada bio je da pomogne u diseminaciji novih pristupa ekonomskoj politici.

\section{LITERATURA}

Beggs, Mike. 2018. The Minsky Millennium. Jacobin, https://jacobinmag.com/2018/11/ the-minsky-millennium (pristupljeno 15. svibnja 2019).

Blanchard, Olivier. 2019. Public Debt and Low Interest Rates. Peterson Institute for International Economics Working Paper 19-4, https://www.piie.com/publications/ working-papers/public-debt-and-low-interest-rates (pristupljeno 11. svibnja 2020).

Blanchard, Olivier i Jean Pisani-Ferry. 2020. Monetisation: Do not panic. VOX CEPR Policy Portal, https://voxeu.org/article/monetisation-do-not-panic?utm_source= hootsuite\&utm_medium $=\& u t m \_t e r m=\& u t m \_c o n t e n t=\& u t m \_c a m p a i g n=$ (pristupljeno 12. svibnja 2020).

Congressional Budget Office. 2020. CBO's Current Economic Projections and a Preliminary Look at Federal Deficits and Debt for 2020 and 2021, https://www.cbo.gov/ system/files/2020-04/56344-CBO-presentation.pdf (pristupljeno 11. svibnja 2020). 
Čavrak, Vladimir. 2019. Makroekonomija krize Covid-19 i kako pristupiti njenom rješavanju. EFZG Working Paper 20-03, https://www.researchgate.net/profile/ Vladimir_Cavrak/publication/340620777_Makroekonomija_krize_Covid-19_i_ kako_pristupiti_njenom_rjesavanju/links/5e95827c4585150839db0dd9/Makroekonomija-krize-Covid-19-i-kako-pristupiti-njenom-rjesavanju.pdf (pristupljeno 11. svibnja 2020).

Eichengreen, Barry. 2013. Exorbitant Privilege: The Rise and Fall of the Dollar. Oxford University Press. Oxford.

Epstein, Gerald. 2019. The Institutional, Empirical and Policy Limits of 'Modern Money Theory'. Political Economy Research Institute, University of MassachusettsAmherst, Working paper br. 481.

Friedman, Milton. 1992. Kapitalizam i sloboda. Globus. Zagreb.

Fullwiller, Scott. 2009. The Sector Financial Balances Model of Aggregate Demand. New Economic Perspectives, http://neweconomicperspectives.org/2009/07/sectorfinancial-balances-model-of_26.html (pristupljeno 28. travnja 2019).

Galbraith, James. 2019. Modern Monetary Realism. Project Syndicate, https://www. project-syndicate.org/commentary/modern-monetary-theory-opponents-misunderstanding-by-james-k--galbraith-2019-03 (pristupljeno 24. travnja 2019).

Godley, Wynne. 2005. Some Unpleasant American Arithmetic. Levy Economics Institute, http://www.levyinstitute.org/publications/some-unpleasant-american-arithmetic (pristupljeno 28. travnja 2019).

Graeber, David. 2013. Dug: Prvih 5000 godina. Fraktura. Zagreb.

Henwood, Doug. 2019. Modern Monetary Theory Isn’t Helping. Jacobin, https://jacobinmag.com/2019/02/modern-monetary-theory-isnt-helping (pristupljeno 30. listopada 2020).

Herndon, Thomas, Michael Ash i Robert Pollin. 2014. Does High Public Debt Consistently Stifle Economic Growth? A Critique of Reinhart and Rogoff. Cambridge Journal of Economics, (38), 2: 257-279.

Hoexter, Michael. 2018. Alexandria on the Daily Show: The Moral Economy and Modern Money. New Economic Perspectives, http://neweconomicperspectives. org/2018/08/alexandria-on-the-daily-show-the-moral-economy-and-modern-money.html (pristupljeno 15. svibnja 2019).

Kaboub, Fadhel. 2012. From Neoliberalism to Social Justice: The Feasibility of Full Employment in Tunisia. Review of Radical Political Economics, (44), 3: 305-312.

Keen, Steve. 2017. Does Modern Monetary Theory Make Sense?, https://www.youtube. $\mathrm{com} /$ watch? $\mathrm{v}=\mathrm{J} 7$ YyarcTLGo (pristupljeno 24. travnja 2019).

Kelton, Stephanie. 1998. Can Taxes and Bonds Finance Government Spending. Levy Economics Institute, Working paper br. 244, http://www.levyinstitute.org/publications/ can-taxes-and-bonds-finance-government-spending (pristupljeno 27. travnja 2019). 
Kelton, Stephanie. 2011. MMT, Sectoral Balances and Behavior. New Economic Perspectives, https://neweconomicperspectives.org/2011/06/mmt-sectoral-balancesand-behavior.html (pristupljeno 28. travnja 2019).

Keynes, John Maynard. 2015 [1936]. Opća teorija zaposlenosti, kamata i novca. Hrvatska gospodarska komora. Zagreb.

Knapp, Georg Friedrich. 1924 [1905]. The State Theory of Money. Macmillan. London.

Krugman, Paul. 2019a. Running on MMT (Wonkish). New York Times, https://www. nytimes.com/2019/02/25/opinion/running-on-mmt-wonkish.html (pristupljeno 24 . travnja 2019).

Krugman, Paul. 2019b. What's Wrong with Functional Finance? (Wonkish). New York Times, https://www.nytimes.com/2019/02/12/opinion/whats-wrong-with-functional-finance-wonkish.html?module=inline (pristupljeno 24. travnja 2019).

Lavoie, Marc. 2013. The Monetary and Fiscal Nexus of Neo-Chartalism: A Friendly Critique. Journal of Economic Issues, (47), 1: 1-32.

Lerner, Abba. 1943. Functional Finance and the Federal Debt. Social Research, (10), 1: 38-51.

Lovrinović, Ivan i Marija Ivanov. 2009. Monetarna politika. RRIF Plus. Zagreb.

Mankiw, N. Gregory. 2019. A Skeptic's Guide to Modern Monetary Theory. NBER Working Paper 26650, https://www.nber.org/papers/w26650.pdf (pristupljeno 11. svibnja 2020).

Marx, Karl i Friedrich Engels. 1979 [1939]. Grundrisse (Osnovi kritike političke ekonomije - Ekonomski rukopisi 1857-1859, prvi deo), u: Marx-Engels Dela, 19. svezak. Institut za međunarodni radnički pokret. Prosveta. Beograd.

McLeay, Michael, Amar Radla i Ryland Thomas. 2014. Money Creation in the Modern Economy. Bank of England Quarterly Bulletin, (1), https://www.bankofengland. co.uk/quarterly-bulletin/2014/q1/money-creation-in-the-modern-economy (pristupljeno 14. svibnja 2020).

Minsky, Hyman P. 1975. John Maynard Keynes. McGraw Hill. New York.

Minsky, Hyman P. 1986. Stabilizing an Unstable Economy. Yale University Press. New Haven, CT.

Minsky, Hyman P. 2013. Ending Poverty: Jobs, Not Welfare. Levy Economics Institute. Annandale-on Hudson, NY.

Mitchell, William. 1998. The Buffer Stock Employment Model and the NAIRU: The Path to Full Employment. Journal of Economic Issues, (32), 2: 547-555.

Mitchell, William, L. Randall Wray i Martin Watts. 2019. Macroeconomics. Macmillan. Oxford.

Mosler, Warren. 2010. Seven Deadly Innocent Frauds of Economic Policy. Valance. St. Croix, US Virgin Islands. 
Mosler, Warren. 2013 [1995]. Soft Currency Economics. Create Space Independent Publishing Platform.

Nersisyan, Yeva i L. Randall Wray, 2020. The Myth of "Helicopter Money". Project Syndicate, https://www.project-syndicate.org/commentary/modern-monetary-theoryis-not-helicopter-money-by-yeva-nersisyan-and-1-randall-wray-2020-04?fbclid= IwAR0ZmrFwrHu9DWqgd2wbz-nwiiQNkiJjrRs4G0ySzTImj97Zj24znC0vxOE (pristupljeno 12. svibnja 2020).

Palley, Thomas. 2015. The Critics of Modern Money Theory (MMT) Are Right. Review of Political Economy, (27), 1: 45-61.

Palley, Thomas. 2019. What's Wrong With Modern Money Theory (MMT): A Critical Primer. Forum for Macroeconomics and Macroeconomic Policies, Working paper br. 44, Hans Böckler Stiftung, https://www.boeckler.de/pdf/p_fmm_imk_ wp_44_2019.pdf (pristupljeno 10. travnja 2019).

Phillips, Leigh i Michael Rozworski. 2019. People's Republic of Walmart: How the World's Biggest Corporations are Laying the Foundations for Socialism. Verso. London i New York.

Radošević, Dubravko i Stjepan Zdunić. 2018. Trilema otvorene ekonomije: Europski semestar, platna bilanca i rast Hrvatske. Jesenski i Turk. Zagreb.

Reinhart, Carmen i Kenneth Rogoff. 2010. Growth in a Time of Debt. American Economic Review, (100), 2: 573-578.

Roberts, Michael. 2017. The Profit-Investment Nexus: Keynes or Marx. Izlaganje na konferenciji Historical Materialism, https://thenextrecession.files.wordpress. com/2017/06/the-profit-investment-nexus-michael-roberts-hmny-april-2017.pdf (pristupljeno 15. svibnja 2019).

Roberts, Michael. 2019a. Modern Monetary Theory - Part 1: Chartalism and Marx. The Next Recession, https://thenextrecession.wordpress.com/2019/01/28/modern-monetary-theory-part-1-chartalism-and-marx/ (pristupljeno 25. travnja 2019).

Roberts, Michael. 2019b. MMT 2: The Tricks of Circulation. The Next Recession, https:// thenextrecession.wordpress.com/2019/02/03/mmt-2-the-tricks-of-circulation/ (pristupljeno 25. travnja 2019).

Roberts, Michael. 2019c. MMT 3: A Backstop to Capitalism. The Next Recession, $\mathrm{https}$ ://thenextrecession.wordpress.com/2019/02/05/mmt-3-a-backstop-to-capitali$\mathrm{sm} /$ (pristupljeno 25. travnja 2019).

Roberts, Michael. 2019d. MMT, Minsky, Marx and the Money Fetish. The Next Recession, https://thenextrecession.wordpress.com/2019/02/26/mmt-minsky-marx-andthe-money-fetish (pristupljeno 25. travnja 2019).

Roberts, Michael. 2019e. Macro Modelling MMT. The Next Recession, https://thenextrecession.wordpress.com/2019/03/03/macro-modelling-mmt/ (pristupljeno 25. travnja 2019). 
Rogoff, Kenneth. 2019. Modern Monetary Nonsense. Project Syndicate, https://www. project-syndicate.org/commentary/federal-reserve-modern-monetary-theory-dangers-by-kenneth-rogoff-2019-03 (pristupljeno 15. svibnja 2019).

Ruml, Beardsley. 1946. Taxes for Revenue are Obsolete. American Affairs, (8), 1: 35-39.

Sajter, Domagoj. 2018. Novi pogled na novac: Moderna monetarna teorija, http://domagoj-sajter.from.hr/?p=1047\#.XNv9UY4zaUk (pristupljeno 15. svibnja 2019).

Shaikh, Anwar. 2016. Capitalism: Competition, Conflict, Crises. Oxford University Press. Oxford.

Skidelsky, Robert. 2018. Money and Government: The Past and Future of Economics. Yale University Press. New Haven i London.

Stiglitz, Joseph E. 2018. The Myth of Secular Stagnation. Project Syndicate, https:// www.project-syndicate.org/commentary/secular-stagnation-excuse-for-flawed-policies-by-joseph-e-stiglitz-2018-08?barrier=accesspaylog (pristupljeno 30. travnja 2019).

Summers, Lawrence. 2014. US Economic Prospects: Secular Stagnation, Hysteresis, and the Zero Lower Bound. Business Economics, (49), 2: 65-73.

Summers, Lawrence. 2019. The Left's Embrace of Modern Monetary Theory is a Recipe for Disaster. Washington Post, https://www.washingtonpost.com/opinions/the-lefts-embrace-of-modern-monetary-theory-is-a-recipe-for-disaster/2019/03/04/6ad88eec3ea4-11e9-9361-301ffb5bd5e6_story.html?utm_term=.a6f678a9a9d8 (pristupljeno 24. travnja 2019).

Tcherneva, Pavlina R. 2013. Beyond Full Employment: What Argentina's Plan Jefes Can Teach Us about the Employer of Last Resort, u: Forstater, Matthew i Murray, Michael J. (ur.): The Job Guarantee: Toward Full Employment. New York. Palgrave Macmillan.

Wiesenthal, Joe. 2012. Goldman's Top Economist Explains the World's Most Important Chart, and his Big Call for the US Economy. Business Insider, https://www.businessinsider.com/goldmans-jan-hatzius-on-sectoral-balances-2012-12 (pristupljeno 28. travnja 2019).

Wray, L. Randall. 1998. Understanding Modern Money: The Key to Full Employment and Price Stability. Edward Elgar. Cheltenham.

Wray, L. Randall. 1999. Theories of Value and the Monetary Theory of Production. Levy Economics Institute, Working Paper br. 261, https://papers.ssrn.com/sol3/papers. cfm?abstract_id=150497 (pristupljeno 25. travnja 2019).

Wray, L. Randall. 2015. Modern Money Theory: A Primer on Macroeconomics for Sovereign Monetary Systems. Palgrave Macmillan. New York. 


\section{Marko Grdešić \\ WHAT DOES MODERN MONETARY THEORY OFFER?}

\section{Summary}

This article provides an overview of Modern Monetary Theory (MMT). This approach to economic policy emphasizes the autonomous role of the state, its monopoly status in terms of issuing currency and its ability to provide full employment via a job guarantee. The article presents the main theoretical and policy elements of MMT, followed by the main criticisms stemming from liberal, Keynesian and Marxist perspectives. Additionally, this article discusses the possibility that peripheral countries, like Croatia, apply the economic tools suggested by MMT. Given that MMT has transitioned from the relatively marginal terrain of academic debates onto the terrain of more visible public discussion, one can expect that it will be able to shape the economic agenda in coming years.

Keywords: Modern Monetary Theory, Keynesianism, Postkeynesianism, Neoliberalism

Marko Grdešić je docent na Fakultetu političkih znanosti.

Kontakt: Marko Grdešić, Fakultet političkih znanosti, Lepušićeva 6, 10000 Zagreb. E-mail: marko.grdesic@fpzg.hr 